\title{
Analysis Of Intention To Use Electronic Money In Denpasar City: TAM Approach
}

\author{
I. Komang Sumerta \\ Economics and Business Faculty, \\ Udayana University, Bali - Indonesia \\ I. Made Wardana \\ Economics and Business Faculty, \\ Udayana University, Bali - Indonesia
}

\begin{abstract}
The rapid development of technology has penetrated various sectors of life in the community, one of which is in the banking sector. Electronic money has advantages and disadvantages that can affect the behavior of consumers to use it. This study aims to explain the usefulness and perceived consumers' use of electronic money products. The population of this research is infinite. The sampling method used in this study is nonprobability sampling. The sampling technique in this study was purposive sampling. The sample used was 108 respondents. The analytical tool used is Warp PLS 3.0 The results of this study are perceived usefulness and perceived ease of use has a positive and significant effect on using electronic money. Perceived usefulness have a positive and significant effect on the intention to use electronic money. The attitude of using electronic money has a positive and significant effect on the intention to use electronic money. Perceived ease of use have a positive and significant effect on the perceived the usefulness of electronic money. The practical implication of electronic money issuing companies can improve and improve in terms of the community's intention to use electronic money as a medium for future micropayment transactions. Factors that influence the intention to use in this study are perceived usefulness, perceived ease and attitude. Theoretical implications in this study to enrich the concept of consumer behavior in marketing, especially the results of previous research on the intention of using electronic money.
\end{abstract}

Keywords: TAM, Intention of Use, Electronic Money

\section{INTRODUCTION}

The rapid development of technology has penetrated many sectors of life in society, one of which is in an k kan PERB sector. Advances in technology in the se c tor has been very rapid banking case, from the advent of automated teller machines (ATMs), mobile banking, to internet banking. The technological progress did not stop there, in 2009 the Indonesian government together with Bank Indonesia issued a new banking product based on technology namely electronic money. Technological advancements have an impact on all industries, including the banking industry which currently can facilitate customer banking activities to be more efficient and also friendly to its users (Akinci et al. 2004). In general, technological developments in the field of financial transactions shape consumer behavior to tend to use more effective and efficient transaction tools, one of which is to use non-cash transactions. Non-cash transactions that are currently developing are using electronic money. 
Table 1 .

Cash Transaction Volume and Electronic Money

\begin{tabular}{lccccc}
\hline No. & Year & $\begin{array}{c}\text { Cash } \\
\text { (Billions of Rp.) }\end{array}$ & $\begin{array}{c}\text { E-money } \\
\text { (Billions of Rp.) }\end{array}$ & $\begin{array}{c}\text { Total } \\
\text { (Billions of Rp.) }\end{array}$ & E-Money (\%) \\
\hline 1 & 2010 & 54.158 .062 & 693 & 54.158 .755 & 0.001 \\
\hline 2 & 2011 & 66.921 .296 & 981 & 66.922 .277 & 0,001 \\
\hline 3 & 2012 & 99.396 .764 & 1.971 & 99.398 .735 & 0,002 \\
\hline 4 & 2013 & 90.959 .927 & 2.907 & 90.962 .834 & 0,003 \\
\hline 5 & 2014 & 111.795 .756 & 3.319 & 111.799 .075 & 0,003 \\
\hline 6 & 2015 & 112.845 .451 & 5.283 & 112.850 .734 & 0,005 \\
\hline 8 & 2016 & 111.827 .354 & 7.063 & 111.834 .417 & 0,006 \\
\hline$*$ ) Until October 2017 & 96.847 .623 & 1.264 & 96.848 .887 & 0,001 \\
\hline
\end{tabular}

Source: Bank Indonesia, 2017.

Electronics money is the latest instrument in a payment system, electronic money defined by Soefianto (2012) as a means of payment has the following elements; issued on the basis of the value of money deposited in advance, the value of money stored electronically in a medium such as a server or chip, used as a means of payment to traders who are not issuers of electronic money, as well as the value of electronic money deposited by the holder and managed by the issuer rather than is a deposit as referred to in the law governing banking. The increasingly widespread issuance of electronic money issued by banking and non-banking institutions such as; Bank Mandiri withe-toll product, BCA with the Flazz Card product, PT. Telekomunikasi Indonesia with FlexiCash products, and Telkomsel with $T$ cash products which raises competition so tightly in the electronic money business.

The development of electronic money in Indonesia is very rapid since it was issued in 2009 ago. According to data from Bank Indonesia (2017) until October 2017 the number of electronic money circulating in the community reached $75,846,689$ units, a very significant increase from the 2010 data which only amounted to 7,914,018 units. In sum, electronic money has indeed increased, but this increase has continued to decline since 2013. In 2017 the use of electronic money is still categorized as low because it is still below 1 percent which is still far from the expectations of Bank Indonesia which targets the use of electronics can reach 1 percent of total transactions (Bisnis.com, 2014).

Electronic money has advantages and disadvantages that can affect the behavior of consumers to use it. Consumer behavior is the behavior shown by consumers in finding, buying, using, evaluating and disposing of products and services that are expected to meet various needs (Schiffman and Kanuk, 2010). In this case, individuals who are consumers have the right to accept or reject a product, is one form of consumer behavior (Howard and Sheth, 1979) explains that the theory of consumer behavior can be seen from the process, namely the input in the form of marketing stimuli and the environment that will produce output in the form of attitude (attitude toward behavior), intention (attention), and purchase behavior (purchase behavior ). This basis is used (Davis, 1985) in developing a technology adoption intention model, namely Technology Acceptance Model (TAM) is influenced by two indicators, namely perceived usefulness and perceived ease of use that can affect the use of behavior. information Technology. This attitude will affect the intention, and then the intention will influence the use of information technology.

Considering electronic money is a new product in the world of financial transactions and based on the use of high technology, the Technology Acceptent Model (TAM) theory is very appropriate to explain how the intentions of prospective electronic money consumers are seen from their attitudes and perceived usefulness and perceived ease of use of the product. . 
In the development of research carried out based on TAM, there are inappropriate results between one study and another. In a study conducted by Yadav et al. (2015) found that perceived ease of use did not have a positive and significant effect on consumer attitudes in the use of internet banking, this indicates that consumers feel that it is not easy to use internet banking and this result is contrary to the concept of the TAM itself which states that ease of use perceived influence positive attitude. Several other studies have found that perceived usefulness have a significant and significant effect on the intention to use (Hasio and Tang, 2013., Dakduk et al. 2017) but several other studies get different results, where in a study conducted by Mutianah et al (2012), Yadav et al. (2014) and Wei et al.(2017) found the opposite, namely the perceived usefulness did not have a significant effect on use. Research conducted by Wei et al. (2017) states that all variables in TAM, both perceived usefulness, perceived ease of use and attitude have no significant effect on intention. This is what encourages researchers to conduct research with the research subject is TAM with electronic money as the object of research.

Research that uses electronic money as an object of research is still very rarely done, previous research on electronic money was conducted in Jakarta (Rahmatsyah, 2011). Research on electronic money with the TAM approach in major cities in Bali has never been done. Based on the above background, the research aims to:

1) To explain the effect of perceived usefulness on attitudes using electronic money.

2) To explain the effect of perceived ease of use on the attitude of using electronic money.

3) To explain the influence of attitudes towards the intention of using electronic money?

4) To explain the effect of perceived usefulness on electronic use intentions.

5) To explain the effect of perceived ease of use on the perceived the usefulness of electronic money.

\section{Marketing Strategy Concept}

\section{LITERATURE REVIEW}

The marketing concept is a social and managerial process in which individuals and groups obtain what they need (needs) and desire (wants) through the creation, supply and exchange of everything that has value (value) with another person or group (Kotler, 1999). To apply the concept of marketing, organizations must understand and remain with their customers to provide products and services thatconsumers will buy and use (Hawkins 2001).

\section{Influence of Marketing Strategies}

To develop an effective marketing strategy, there are aspects that influence the marketing process as explained in the Wheel of Consumer Analysis theory (Peter and Olson, 2008). This theory explains three aspects that influence effectiveness in marketing strategies, namely consumer effect and cognition, consumer behavior, and consumer environment.

In Teor e tis, affective and cognitive aspects refer to other types of reactions or psychological response to a stimulus from the events that occurred in the neighborhood. The aspect of consumer behavior is an important factor in marketing strategies. According to Schifmann and Kanuk (2010), the definition of consumer behavior is the behavior shown by consumers in finding, buying, using, evaluating, and disposing of products and services that are expected to meet various needs. The last aspect is the environment that refers to what is a factor external to the consumer which influences the consumer on what they think, feel, and do. 


\section{Consumer Knowledge of Products ( Consumer's Knowledge )}

Consumers have different knowledge of a product. This knowledge is used as an interpretation of information in making purchasing decisions. The level of product knowledge can be categorized by class, form, brand, and model or feature. Peter and Olson (1998), argues that the types of consumer knowledge about the product can be categorized into three categories: product sebgai collection of attributes, a collection of benefits and value satisfaction.

\section{Consumer Engagement (Consumer's Involvement)}

Consumer involvement is referring to consumers' perceived things that are related or important from certain products, events or activities (Peter and Olson, 2008). This involvement occurs when consumers perceive or consider a product, service or marketing message to fulfill their goals and needs. Consumer involvement or participation influences the level of information search, decision making processes, the formation of beliefs, attitudes, intentions and behaviors, for example looking for product variations, trying other product brands, brand loyalty, frequency of product use (Beharrel and Dennison, 1995).

\section{Consumer Perception.}

Consumer perception is a feeling or impression that a consumer has on a product. Perception can be formed from consumer experience, as well as from the impression instilled by producers, among others through the applied marketing communication. Consumer perception can affect the overall decision making process in determining the purchase or use of a product.

\section{Theory of Reasoned Action (TRA)}

This theory was developed by Fishbein and Ajzen (1975) and compiled using basic assumptions that humans are creatures with reason to decide what behavior to take, in a conscious manner and consider all available information. This TRA explains that behavior is carried out because individuals have the intention or desire to apply it.

\section{Theory of Planned Behavior (TPB)}

This theory is a development of TRA. This TPB develops TRA by adding a construct that is perceived behavioral control will affect intention and behavior (Ajzen, 1991). At TPB there are three main factors as determinants of intention, first is an attitude that reflects the extent to which individuals have an assessment of agreeing or disagreeing to conduct behavior. Second, social factors are also calledsubjective norms, referring to perceived social pressure to do or not conduct behavior. The last is behavior control, which refers to perceived ease or difficulty in performing behavior.

\section{Technology Acceptance Model (TAM) Theory}

The Technology Acceptance Model (TAM) developed by Fred Davis (1989) describes the acceptance of technology that will be used by technology users. This theory was adopted from several models that were built to analyze and understand the factors that influence the acceptance of the use of new technologies, including those recorded in various literature and references to research results in the field of information technology are Theory of Reasoned Action (TRA) and Theory of Planned Behavior (TPB).

\section{CONCEPTUAL FRAMEWORK}

Taking into account all the exposures to the theories described above, along with the positive and negative aspects that exist in these theories, a model of a thinking and conceptual framework is arranged as shown below: 


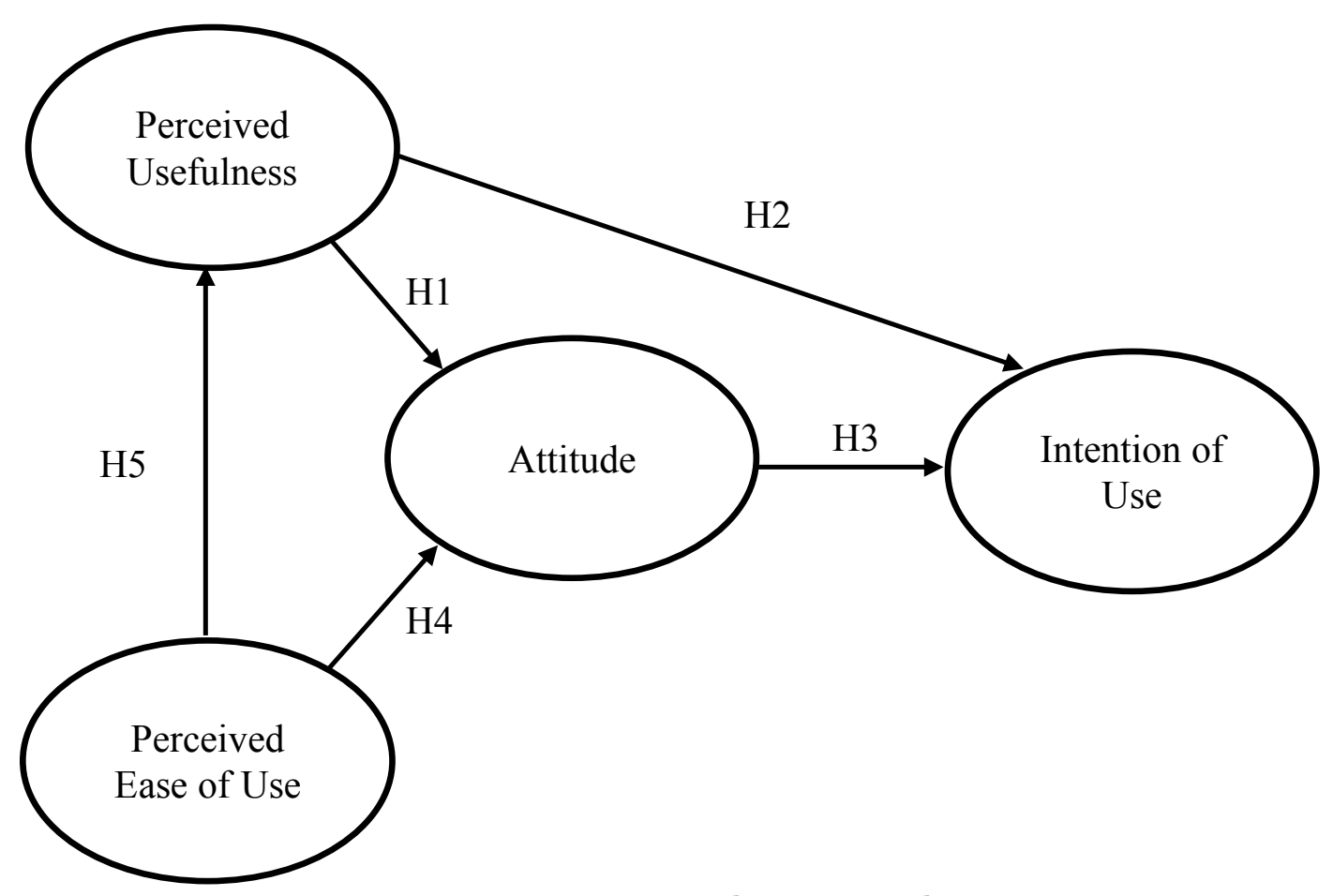

Figure 1. Conceptual Framework

The researcher does not correlate the influence between perceived ease of use and intention of use because based on the existing theory, it is less strengthening the relationship between these variables. Based on the theory, the usage intention is influenced by the perceived usefulness and attitudes of the consumers, while the perceived ease has a relationship with perceived usefulness and attitude, because if someone feels easy in using e-money, it will feel e-money has benefits and consumers will determine their attitude against the existence of emoney. The ease of using e-money will not necessarily attract someone's interest in using emoney because if switching to a new payment method one needs more things that can encourage his interest in using e-money such as perceived usefulness and attitude.

\section{Research Hypothesis:}

H1: Perceived usefulness have a positive and significant effect on the attitude of using electronic money.

H2: Perceived usefulness has a positive and significant effect on intention to use electronic money.

H3: The attitude of use has a positive and significant effect on the intention to use electronic money.

H4: Perceived ease of use have a positive and significant effect on the attitude of using electronic money.

H5: Perceived ease of use have a positive and significant effect on the perceived the usefulness of using electronic money.

\section{RESEARCH METHODS}

To get good research results, research design is needed to support and provide systematic research results. This study uses a quantitative approach that is analyzed associatively. Associative research is research that aims to determine the influence or relationship of a variable or more (Nugroho, 2005: 25) . To get good research results, research design is needed to support and provide systematic research results. This study uses a 
quantitative approach that is analyzed associatively. Associative research is research that aims to determine the influence or relationship of a variable or more (Nugroho, 2005: 25) .

Table 2.

Variable Operational Definition

\begin{tabular}{|c|c|c|}
\hline Variable & Indicator & Source \\
\hline Perceived Usefulness $\left(\mathrm{X}_{1}\right)$ & $\begin{array}{l}\text { PU1 = Speed up the payment } \\
\text { process } \\
\text { PU2 = Increases the accuracy of the } \\
\text { payment process } \\
\text { PU3 = Feel safer } \\
\text { PU4 = Give attractive promotions } \\
\text { PU5 = More efficient }\end{array}$ & $\begin{array}{l}\text { Taylor and Todd (1995c), Mafe et } \\
\text { al. (2009), Rigopouos and Askounis } \\
(2007) .\end{array}$ \\
\hline Perceived Ease of Use $\left(\mathrm{X}_{2}\right)$ & $\begin{array}{l}\text { PEOU1 }=\text { Ease of use } \\
\text { PEOU2 }=\text { Ease of understanding } \\
\text { PEOU3 }=\text { Practical in use } \\
\text { PEOU4 = Flexibility }\end{array}$ & $\begin{array}{l}\text { Rigopouos and Askounis (2007), } \\
\text { Davis (1989). }\end{array}$ \\
\hline Attitude $\left(\mathrm{Y}_{1}\right)$ & $\begin{array}{l}\text { A1 }=\text { Desired } \\
\text { A2 }=\text { Useful } \\
\text { A3 }=\text { OK } \\
\text { A4 }=\text { Fun }\end{array}$ & $\begin{array}{l}\text { Taylor and Todd (1995c), } \\
\text { Bhattacherjee (2000), Peslak et } \\
\text { al.(2010 }\end{array}$ \\
\hline Intention $\left(\mathrm{Y}_{2}\right)$ & $\begin{array}{l}\text { ITU1 }=\text { Looking for Information } \\
\text { ITU2 }=\text { Willing to Buy } \\
\text { ITU3 }=\text { Finding Out } \\
\text { ITU4 }=\text { Learn } \\
\text { ITU5 }=\text { Willing to use }\end{array}$ & $\begin{array}{l}\text { Taylor and Todd (1995c), } \\
\text { Rigopoulos and Askounis (2007), } \\
\text { Peslak et al. (2010) }\end{array}$ \\
\hline
\end{tabular}

\section{Source: Data processed, 2018}

Based on its nature, the type of data used in this study is quantitative data. Quantitative data is data that can be calculated and in the form of numbers (Nugroho, 2005: 27). Data were quantified in this research that the data can be a number in the results of the questionnaire data that have been distributed.

Primary data sources come from distributing questionnaires to respondents in accordance with predetermined criteria that have been obtained directly from respondents regarding perceived usefulness, perceived ease of use, attitude and intention to use electronic money. The population used in this study is the prospective consumer of electronic money located in Denpasar whose numbers cannot be identified. The sample determination method used in this study is non-probability sampling where this technique does not provide equal opportunities or opportunities for each element or member of the population to be chosen as a sample (Sugiyono, 2015: 44).

The sampling technique in this study was purposive sampling. This purposive sampling technique is a technique that determines a sample based on certain considerations and is determined intentionally by the researcher (Nugroho, 2005: 40). In this study using 18 indicators so that the number of respondents used for the sample is $18 \times 6=108$ respondents. Determination of a sample of 108 respondents in accordance with the provisions of sampling to obtain maximum results should be used larger or equal to 100 samples. The measurement scale used in this study is the Likert scale, which is a scale that has been widely used to ask respondents to mark the degree of approval or disagreement with a series of stimulus objects. The Likert scale used is 1 to strongly disagree to 5 strongly agree. 


\section{Data analysis technique}

\section{Inferential Statistical Analysis}

Data analysis in this study used Partial Least Square (PLS) approach . PLS is an equation model for Structural Equation Modeling (SEM) based on components or variants. To praise the hypothesis and produce a feasible model, this study uses Structural Equation Modeling (SEM) with a variance based or component based approach with Partial Least Square (PLS). If the structural model to be analyzed meets the recrusive model and the latent variable has normative indicators. Reflective or mixed, the most appropriate approach to use is PLS.

\section{Characteristics of Respondents}

\section{RESEARCH RESULT}

Table 3.

Characteristics of Respondents

\begin{tabular}{|c|c|c|c|c|c|}
\hline \multirow{2}{*}{ No. } & \multirow{2}{*}{ Variable } & \multirow{2}{*}{ Classification } & \multirow[b]{2}{*}{ amount } & \multicolumn{2}{|c|}{ Percentage } \\
\hline & & & & & $(\%)$ \\
\hline \multirow[t]{8}{*}{1} & Age (year) & $19-23$ & 26 & & 24.1 \\
\hline & & $24-28$ & 57 & & 52.8 \\
\hline & & $29-33$ & 16 & & 14.8 \\
\hline & & $34-38$ & 5 & & 4,6 \\
\hline & & $39-43$ & 1 & & 0.9 \\
\hline & & $44-48$ & 1 & & 0.9 \\
\hline & & $49-53$ & 1 & & 0.9 \\
\hline & & $54-58$ & 1 & & 0.9 \\
\hline \multirow[t]{2}{*}{2} & Gender & Woman & 42 & & 38.9 \\
\hline & & Man & 66 & & 61.1 \\
\hline \multirow[t]{4}{*}{3} & Last education & High school & & 54 & 50 \\
\hline & & Diploma & & 5 & 4,6 \\
\hline & & Bachelor & & 47 & 13.5 \\
\hline & & Postgraduate & & 2 & 1.9 \\
\hline \multirow[t]{5}{*}{4} & Work & Student / Student & & 15 & 13,9 \\
\hline & & PNS / TNI / POLRI & & 2 & 1.9 \\
\hline & & Private employees & & 85 & 78.7 \\
\hline & & Entrepreneur & & 2 & 1.9 \\
\hline & & Professional & & 4 & 3.7 \\
\hline \multirow[t]{6}{*}{5} & Expenditures in 1 month & IDR $1,000,000$ - IDR $2,750,000$ & & 55 & 50,9 \\
\hline & & IDR $2,750,001$ - IDR $4,500,000$ & & 34 & 31.5 \\
\hline & & IDR 4,500,001 - IDR $6,250,000$ & & 16 & 14.8 \\
\hline & & IDR $6,250,000$ - IDR $8,000,000$ & & 1 & 0.9 \\
\hline & & IDR. $9,750,001$ - IDR. $11,500,000$ & & 1 & 0.9 \\
\hline & & IDR $13,250,001$ - IDR $15,000,000$ & & 1 & 0.9 \\
\hline
\end{tabular}

\section{Source: Data processed, 2018}

Table 3 shows several things related to the characteristics of respondents. Referring to the table it can be seen that the male respondents more mmendominasi which amounted to 61, 1 percent compared with 38.9 percent of female respondents. Based on the age group, respondents aged 24 to 28 have the highest percentage, which is 52.8 percent. Based on the respondents' last education, it can be seen that the level of high school education has the highest percentage of 50 percent. Based on the type of work, can be seen in private sector employees have the highest percentage that is equal to 78,7percent. Based on expenditures in one month, it can be seen spending of IDR $1,000,000$ to IDR $2,750,000$ has the highest percentage of 50,9 percent. 


\section{Respondent Answer Distribution}

According to Nata Wirawan (2002: 35) the determination of frequency distribution is based on the interval value, so to obtain the frequency distribution. To find out the overall assessment of the research variables, it will be seen from the average score with the following criteria :

$$
\begin{array}{ll}
1.00-1.79 & =\text { Very Low } \\
1.80-2.59 & =\text { Low } \\
2.60-3.39 & =\text { Neutral } \\
3,40-4,19 & =\text { Height } \\
4,20-5,00 & =\text { Very High }
\end{array}
$$

Based on the results of the study, it can be seen the responses of respondents from each indicator of each variable as follows:

\section{Perceived Usefulness}

\begin{tabular}{|c|c|c|c|c|c|c|c|c|}
\hline \multirow{3}{*}{ No. } & \multirow{3}{*}{ Statement } & \multicolumn{5}{|c|}{ Answer Classification } & \multirow{3}{*}{ Average } & \multirow{3}{*}{ Information } \\
\hline & & STS & TS & $\mathbf{N}$ & $\mathbf{S}$ & SS & & \\
\hline & & 1 & 2 & 3 & 4 & 5 & & \\
\hline 1 & Speed up the payment process & 0 & 1 & 7 & 62 & 38 & 4.27 & Very high \\
\hline 2 & $\begin{array}{l}\text { Increase the accuracy of the payment } \\
\text { process }\end{array}$ & 0 & 4 & 13 & 56 & 35 & 4,13 & High \\
\hline 3 & Feel safer & 1 & 4 & 19 & 48 & 36 & 4.06 & High \\
\hline 4 & Give attractive promotions & 4 & 6 & 30 & 45 & 23 & 3.71 & High \\
\hline 5 & More efficient in transactions & 1 & 1 & 8 & 50 & 48 & 4.32 & Very high \\
\hline \multicolumn{7}{|c|}{$\begin{array}{ll}\text { Average Score Total } \\
\end{array}$} & 4.10 & High \\
\hline
\end{tabular}

Table 4 shows that the total average response score Respondents regarding the usefulness perception variable measured using 5 indicators is 4.10 .

Table 4

Assessment of Respondents on Variables Perceived Benefit

Source: Data processed, 2018

Based on these results that the average respondent's overall answer about the perceived usefulness in the use of electronic money in Denpasar City was high. Indicator with the highest average score is more efficient in transactions of 4.32 .

\section{Ease of Perception}

\begin{tabular}{|c|c|c|c|c|c|c|c|c|}
\hline \multirow{3}{*}{ No. } & \multirow{3}{*}{ Statement } & \multicolumn{5}{|c|}{ Answer Classification } & \multirow{3}{*}{ Average } & \multirow{3}{*}{ Information } \\
\hline & & \multirow{2}{*}{$\begin{array}{r}\text { STS } \\
1 \\
\end{array}$} & \multirow{2}{*}{$\begin{array}{r}\text { TS } \\
2\end{array}$} & \multirow{2}{*}{$\begin{array}{l}\mathbf{N} \\
3\end{array}$} & \multirow{2}{*}{$\begin{array}{l} \\
4\end{array}$} & \multirow{2}{*}{\begin{aligned} \multicolumn{1}{l}{ SS } \\
5\end{aligned}} & & \\
\hline & & & & & & & & \\
\hline 1 & Easy to learn & 1 & 0 & 16 & 75 & 16 & 3.97 & Very high \\
\hline 2 & Easy to use in transactions & 0 & 0 & 13 & 59 & 36 & 4.21 & Very high \\
\hline 3 & Practical in use & 0 & 0 & 7 & 54 & 47 & 4.37 & Very high \\
\hline \multirow[t]{2}{*}{4} & Flexible (used anytime and anywhere) & 1 & 11 & 27 & 45 & 24 & 3.74 & High \\
\hline & $\begin{array}{ll}\text { Average Sco } \\
\end{array}$ & Total & & & & & 4.07 & High \\
\hline
\end{tabular}

Table 5 shows that the total average score of respondents' responses regarding perceived usefulness variables measured using 4 indicators is 4.07.

Table 5

Assessment of Respondents on Ease Perception Variables

Source: Data processed, 2018 
Based on these results that the average respondent's overall answer about the perceived ease of use of electronic money in Denpasar is high. Indicator with the highest average score is practical in usage of 4.37

\section{Attitude}

Table 6 shows that the total average score of respondents' responses regarding attitude variables measured using 4 indicators is 4.06 .

Table 6

Assessment of Respondents on Attitude Variables

\begin{tabular}{|c|c|c|c|c|c|c|c|c|}
\hline \multirow{3}{*}{ No. } & \multirow{3}{*}{ Statement } & \multicolumn{5}{|c|}{ Answer Classification } & \multirow{3}{*}{ Average } & \multirow{3}{*}{ Information } \\
\hline & & STS & TS & $\mathbf{N}$ & $\mathbf{S}$ & SS & & \\
\hline & & 1 & 2 & 3 & 4 & 5 & & \\
\hline 1 & I am very interested in electronic money & 0 & 4 & 10 & 61 & 33 & 4,14 & High \\
\hline 2 & Electronic Money is very useful & 0 & 2 & 15 & 57 & 34 & 4,14 & High \\
\hline 3 & Electronic money is good to use & 0 & 0 & 20 & 59 & 29 & 4.08 & High \\
\hline \multirow[t]{2}{*}{4} & Fun electronic money & 0 & 3 & 26 & 59 & 20 & 3.89 & High \\
\hline & Average Score & otal & & & & & 4.06 & High \\
\hline
\end{tabular}

Source: Data processed, 2018

Based on these results, the average respondent's overall answers to attitudes in the use of electronic money in Denpasar City were high. The indicator with the highest average score is very interested in electronic money and electronic money is very useful at 4.14.

\section{Intention of Use}

Table 7 shows that the total average score of respondents' responses regarding the use intention variable measured using 5 indicators is 4.17 .

Table 7

Assessment of Respondents on Variable Intentions of Use

\begin{tabular}{|c|c|c|c|c|c|c|c|c|}
\hline \multirow{3}{*}{ No. } & \multirow{3}{*}{ Statement } & \multicolumn{5}{|c|}{ Answer Classification } & \multirow{3}{*}{ Average } & \multirow{3}{*}{ Information } \\
\hline & & STS & TS & $\mathbf{N}$ & $\mathbf{S}$ & SS & & \\
\hline & & 1 & 2 & 3 & 4 & 5 & & \\
\hline 1 & $\begin{array}{l}\text { I will look for more detailed information } \\
\text { about electronic money. }\end{array}$ & 0 & 1 & 16 & 61 & 30 & 4,11 & High \\
\hline 2 & I am willing to buy electronic money. & 1 & 2 & 15 & 53 & 37 & 4,14 & High \\
\hline 3 & I will find out where to buy electronic money. & 0 & 3 & 16 & 57 & 32 & 4.09 & High \\
\hline 4 & I will find out how to use electronic money. & 0 & 2 & 11 & 59 & 36 & 4.19 & High \\
\hline 5 & I am willing to use electronic money. & 1 & 2 & 9 & 45 & 51 & 4.32 & Very high \\
\hline \multicolumn{7}{|c|}{$\begin{array}{ll}\text { Average Score Total } \\
\end{array}$} & 4,17 & High \\
\hline
\end{tabular}

Source: Data processed, 2018

Based on these results that the average respondent's overall answer about the intention of using electronic money in Denpasar City was high. Indicator with the highest average score that is willing to use electronic money of 4.32 .

\section{Testing of Research Instruments}

\section{Validity test}

Validity test can be done by correlating between instrument item scores with a total score of all statement items. If the correlation between each item score statement on the total score, the statement points indicate the correlation coefficient value $\geq 0,3$ then each item of the statement is said to be valid (Sugiyono, 2012: 178). 
Table 8

Instrument Validity Test Results

\begin{tabular}{clccc}
\hline No. & Variable & Indicator & Correlation coefficient & Information \\
\hline 1 & Perceived Usefulness & X1.1 & 0.408 & Valid \\
& & X1.2 & 0.688 & Valid \\
& & X1.3 & 0.705 & Valid \\
& & X1.4 & 0.730 & Valid \\
\hline 2 & Ease of Perception & X1.5 & 0.710 & Valid \\
& & X2.1 & 0.493 & Valid \\
& & X2.2 & 0.851 & Valid \\
& & X2.3 & 0.629 & Valid \\
\hline 3 & Attitude & X2.4 & 0.718 & Valid \\
& & Y1.1 & 0.705 & Valid \\
& & Y1.2 & 0.729 & Valid \\
& & Y1.3 & 0.754 & Valid \\
\hline 4 & Intention of Use & Y1.4 & 0.87 & Valid \\
& & Y2.1 & 0.909 & Valid \\
& & Y2.2 & 0.863 & Valid \\
& & Y2.3 & 0.905 & Valid \\
& & Y2.4 & 0.884 & Valid \\
\hline
\end{tabular}

Source: Data processed, 2018

Based on the validity test in Table 8 shows 18 indicators used have a correlation value greater than 0.3 so that the overall indicators used are declared valid.

\section{Reliability Test}

Reliability or reliability testing of instruments shows the extent to which a measurement is returned to the same symptoms. A reliable instrument is an instrument that is used several times to measure the same object will produce the same data or answer. The instrument is said to be reliable if it has a cronbach alpha $\geq 0,60$. (Sugiyono, 2012: 172)

Table 9

Instrument Reliability Test Results

\begin{tabular}{lcl}
\hline \multicolumn{1}{c}{ Variable } & Cronbach's Alpha & Information \\
\hline Perceived Usefulness & 0.845 & Reliable \\
\hline Ease of Perception & 0.676 & Reliable \\
\hline Attitude & 0.941 & Reliable \\
\hline Intention of Use & 0.916 & Reliable \\
\hline
\end{tabular}

Source: Data processed, 2018

\section{DATA ANALYSIS}

\section{Evaluation of the Goodness of fit PLS model.}

Based on the results of Warp-PLS output, the following results are obtained from APC, ARS, and AVIF.

Table 10

Goodness of Fit

\begin{tabular}{lllll}
\hline Fit model & Index & $\boldsymbol{p}$-value & Criteria & Information \\
\hline Average path coefficient (APC) & 0.487 & $\mathrm{P}<0.001$ & $\mathrm{P}<0.050$ & Be accepted \\
\hline Average R-Squared (ARS) & 0,594 & $\mathrm{P}<0.001$ & $\mathrm{P}<0.050$ & Be accepted \\
\hline Average Block Variance Inflation Factor(AVIF) & 1,990 & & $<5$ & Be accepted \\
\hline
\end{tabular}

Source: Data processed, 2018 
Based on the results of the APC and ARS values above, it can be said that the results of this study can be accepted because they meet the criteria of goodness of fit where the APC and ARS values must be smaller than 0.05 (Solihin and Ratmono, 2013; 61) .

\section{Evaluation of Outer Model Reflective Indicators a) Convergent Validity Test}

The results of the evaluation of combined loadings and cross loadings to test the convergent validity of measurement instruments (questionnaires) are presented in table 11 below. To assess whether the outer model meets the conditions of convergent validity for reflective constructs, it can be seen by looking at the $\mathrm{p}$ value of significance which must be $<0.05$ (Solihin and Ratmono, 2013). Based on these criteria, the overall value of cross loading on perceived usefulness variables, perceived ease of use, attitude and intention to use is valid with the $p$ value of each indicator $<0,05$.

Table 11

Output Combined Loading and Cross-Loading Results

\begin{tabular}{|c|c|c|c|c|}
\hline Variable & Indicator & Cross loading & SE & P value \\
\hline \multirow{5}{*}{ Perceived Usefulness } & $\mathrm{X} 1.1$ & 0.662 & 0.156 & 0,000 \\
\hline & $\mathrm{X} 1.2$ & 0.826 & 0.105 & 0,000 \\
\hline & $\mathrm{X} 1.3$ & 0.794 & 0.094 & 0,000 \\
\hline & $\mathrm{X} 1.4$ & 0.660 & 0.134 & 0,000 \\
\hline & $\mathrm{X} 1.5$ & 0.735 & 0.158 & 0,000 \\
\hline \multirow[t]{4}{*}{ Perceived Ease of Use } & $\mathrm{X} 2.1$ & 0.804 & 0.146 & 0,000 \\
\hline & $\mathrm{X} 2.2$ & 0.866 & 0.068 & 0,000 \\
\hline & $\mathrm{X} 2.3$ & 0.781 & 0.089 & 0,000 \\
\hline & $\mathrm{X} 2.4$ & 0.436 & 0.169 & 0.006 \\
\hline \multirow[t]{4}{*}{ Attitude } & Y1.1 & 0860 & 0.101 & 0,000 \\
\hline & Y1.2 & 0.907 & 0.076 & 0,000 \\
\hline & Y1.3 & 0.892 & 0.064 & 0,000 \\
\hline & Y1.4 & 0.886 & 0.071 & 0,000 \\
\hline \multirow[t]{5}{*}{ Intention of Use } & Y2.1 & 0.819 & 0.091 & 0,000 \\
\hline & Y2.2 & 0.849 & 0.091 & 0,000 \\
\hline & Y2.3 & 0.921 & 0.083 & 0,000 \\
\hline & Y2.4 & 0.875 & 0.096 & 0,000 \\
\hline & Y2.5 & 0.811 & 0.107 & 0,000 \\
\hline
\end{tabular}

\section{Source: Data processed, 2018}

\section{b) Test of Discriminant Validity}

This method can be done by looking at the AVE criteria. AVE that is in a diagonal column and has parentheses must be more height of correlation between latent variables in the same column .Here are the results of the AVE calculation:

Table 12

Correlations among latent variables

\begin{tabular}{|c|c|c|c|c|}
\hline \multicolumn{5}{|c|}{ Correlations among ratent variables } \\
\hline & $\begin{array}{c}\text { Perceived } \\
\text { Usefulness }\end{array}$ & $\begin{array}{c}\text { Perceived Ease of } \\
\text { Use }\end{array}$ & Attitude & Intention of Use \\
\hline $\begin{array}{c}\text { Perceived } \\
\text { Usefulness }\end{array}$ & 0.738 & 0.712 & 0.694 & 0.711 \\
\hline $\begin{array}{l}\text { Perceived Ease of } \\
\text { Use }\end{array}$ & 0.712 & 0.741 & 0.733 & 0.672 \\
\hline Attitude & 0.694 & 0.733 & 0.887 & 0.774 \\
\hline Intention of Use & 0.711 & 0.672 & 0.774 & 0.859 \\
\hline
\end{tabular}

Note: Square roots of average variances extracted (AVE's) are shown on diagonal.

Source: Data processed, 2018 
Table 12 shows that the criteria for discriminant validity have been fulfilled as indicated by the square root AVE greater than the correlation coefficient between constructs in each indicator of each variable can measure these variables precisely than with other variables.

\section{a) Test the validity of research instruments}

Table 13

Average variances extracted

\begin{tabular}{lc}
\hline & Average variances extracted \\
\hline Perceived Benefit & 0.545 \\
\hline Perceived Ease of Use & 0.549 \\
\hline Attitude & 0,786 \\
\hline Intention of Use & 0.733 \\
\hline
\end{tabular}

Source: Data processed, 2018 ( Attachment 7)

Average variance extracted (AVE) for each indicator is more than 0,50 , so it can be said that the four constructs meet the convergent validity criteria .

\section{b) Research instrument reliability test}

Table 14

Research instrument reliability test

\begin{tabular}{lcc}
\hline & Composite reliability coefficients & Cronbach's alpha coefficients \\
\hline Perceived Benefit & 0.856 & 0.788 \\
\hline Perceived Ease of Use & 0.822 & 0.708 \\
\hline Attitude & 0.936 & 0.909 \\
\hline Intention of Use & 0.932 & 0.908 \\
\hline
\end{tabular}

Source: Data processed, 2018

The reliability of the research instrument was measured using two measures, composite reliability and cronbach's alpha. Based on these data, each indicator has met the size of composite reliability andCronbach's alpha is $>0,70$.

\section{Inner Model Evaluation}

Inner model evaluation aims to determine the goodness of fit model with the following methods:

\section{a) $R$-Square $\left(R^{2}\right)$}

Shows the strong weak influence caused by variations in exogenous variables on endogenous variables. The $R$-Square value is greater than 0,50 categorized as a strong model. The $R$ Square values of each endogenous variable from the results of data processing performed are presented in the form of Table 15 below:

Table 15

Rated $R$-Square Research

\begin{tabular}{lcc}
\hline & \multicolumn{2}{l}{ R-Square } \\
\hline Perceived Benefit & Value & Criteria (Chin, 1998) \\
\hline Perceived Ease of Use & 0.519 & Strong \\
\hline Attitude & - & \\
\hline Intention of Use & 0.602 & Strong \\
\hline
\end{tabular}

Source: Data processed, 2018

Based on these data the value of the $R$-square construct perceived usefulness of 0.519 indicates that the variance of perceived usefulness can be explained by $51.9 \%$ by the variance of 
perceived ease of use. $R$-squared construct constructs of 0.602 indicate that the variance of attitudes can be explained by $60,2 \%$ by the variance of perceived usefulness, and the perceived ease of use. $R$-squared construct of use intention of 0.661 indicates that the variance of use intention can be explained by $66.1 \%$ by variance of perceived usefulness, and attitude .

\section{b) Q-Square}

$Q$-square predictive relevance to measure how well the observation value is generated by the model and its parameter estimates. Value $Q$-square $>0$ indicates the model has predictive relevance, otherwise if the value of the Q-square $<0$ indicates the model lacks predicttive relevance.

Table 16

Value Q-Square Research

\begin{tabular}{lc}
\hline & Q-Square \\
\hline Perceived Benefit & 0.521 \\
\hline Perceived Ease of Use & - \\
\hline Attitude & 0.605 \\
\hline Intention of Use & 0.664 \\
\hline
\end{tabular}

\section{Source: Data processed, 2018}

Q-square is the result of testing predictive validity and the value must be greater than zero (Solihin and Ratmono, 2013). The model estimation results show good predictive validity of $0.521,0.605$ and 0.664 , so that the value is above zero, which means that the predictive validity of each of these variables is categorized as good. The overall Q-Square (Predictive Relevance ) value of the model can be calculated as follows:

$$
\begin{aligned}
& Q_{2}=1-\left(1-R_{21}\right)\left(1-R_{2}\right)\left(1-R_{2}\right) \\
& Q_{2}=1-(1-0.519)(1-0.602)(1-0.661) \\
& Q_{2}=1-(0.481)(0.398)(0.339) \\
& Q_{2}=1-0.0649 \\
& Q_{2}=0.9351
\end{aligned}
$$

The calculation above obtained value of $\mathrm{Q}^{2}$ at 0.9351 , so that the value is greater than 0 and thus may otherwise good predictive validity.

\section{a) Testing Variable Relationship Statistics}

Testing of variable relationship statistics can be seen by looking at the effect size value which is calculated as the absolute value of individual contributions for each latent variable predictor on the value of $R$-Square $\mathrm{d}$.

Table 17

Path Coefficient

\begin{tabular}{lclcccc}
\hline & & & $\begin{array}{c}\text { Standard } \\
\text { Error }\end{array}$ & $\begin{array}{c}\text { Effect } \\
\text { Size }\end{array}$ & $\begin{array}{c}\text { Path } \\
\text { coefficients }\end{array}$ & $\begin{array}{c}P \\
\text { values }\end{array}$ \\
\hline Perceived Usefulness & $\rightarrow$ & Attitude & 0.097 & 0.247 & 0.354 & 0.001 \\
\hline Perceived Usefulness & $\rightarrow$ & Intention of Use & 0.077 & 0.235 & 0.330 & 0.001 \\
\hline Perceived Ease of Use & $\rightarrow \begin{array}{l}\text { Perceived } \\
\text { Usefulness }\end{array}$ & 0.074 & 0.519 & 0.720 & 0.001 \\
\hline Perceived Ease of Use & $\rightarrow$ & Attitude & 0.090 & 0.355 & 0.484 & 0.001 \\
\hline Attitude & $\rightarrow$ & Intention of Use & 0.074 & 0.426 & 0.547 & 0.001 \\
\hline
\end{tabular}

Source: Data processed, 2018 
Size effects can be grouped into three categories: weak (0.02), medium (0.15), and large (0.35) (Solihin and Ratmono, 2013; 33). Table 5.16 shows that the effect size value of each variable is greater than 0.2 so that it is in the medium and large category. Testing of variable relationship statistics can also be seen from the value of the path coefficients for each variable relationship shows apositive and significant relationship because p-value is less than 0.05 (Solihin and Ratmono, 2013; 62) .

Figure 2. Model testing results

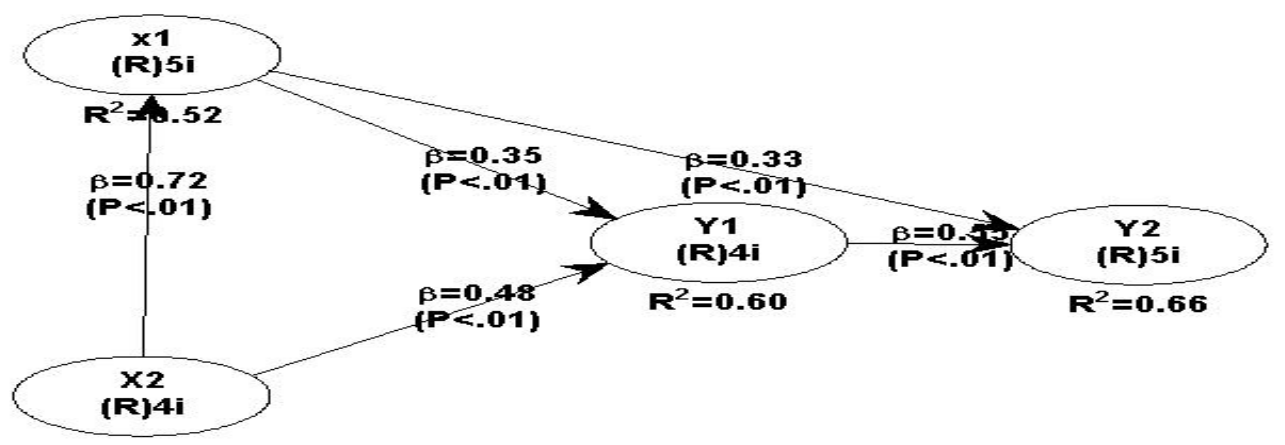

Source: Data processed, 2018

\section{DISCUSSION}

The influence of perceptions of usefulness on the attitude of using electronic money

The results of hypothesis testing show that perceptions of usefulness have a positive and significant effect on the attitude of using electronic money. This result means that the more a person feels that electronic money is beneficial, it will encourage someone to be positive about the use of electronic money. This is supported by research such as that conducted by Alagoz and Hekimoglu, (2012 ), Yadav et al. (2015), Bailey et al. (2017), Ma et al. (2017) and Wei et al. (2017) get the same results, namely the Perceived usefulness has a positive effect on attitude.

\section{The influence of perceptions of usefulness on the intention of using electronic money}

Based on the hypothesis test, it is found that the Perceived usefulness has a positive and significant effect on the intention of using electronic money. This means that the more someone feels electronic money is useful, the person will have more intention to use electronic money. This is consistent with the research conducted by Giovanis et al. (2012) ,

Safeena et al. (2013), Awa et al. (2015),Dakduk et al. (2017) and Wei et al. (217) found that perceptions of usefulness have a positive and significant effect on consumer intentions .

\section{The effect of usage attitude on the intention of using electronic money.}

Based on the hypothesis test found that the attitude of using electronic money has a positive and significant effect on the intention of using electronic money. This means that the more a person has a positive attitude towards the use of electronic money, it will be possible to increase the person's intention to use electronic money. This is consistent with the research of Yadav, et al. (2015), Dakduk et al.(2017) and Wei et al. (2017) found that attitude had a positive and significant effect on intention .

\section{Effect of perceptions of ease of use on the attitude of using electronic money.}

Based on the hypothesis test found that the Perceived ease of use has a positive and significant effect on the attitude of using electronic money. This means that the more someone feels the ease with the existence of electronic money, the person will have a more positive attitude 
towards electronic unag. This is consistent with previous research that the Perceived ease of use has a positive and significant effect on attitudes, such as research conducted by Hsiao and Tang (2014), Dakduk et al. (2017) and Wei et al. (2017) .

\section{The influence of perceptions of ease of use on the Perceived the usefulness of electronic money}

Based on the hypothesis test found that the Perceived ease of use has a positive and significant effect on the Perceived the usefulness of electronic money. This means that the more a person feels that the ease gained by using electronic money will improve one's perception related to the usefulness of electronic money. This is supported by research by Rauniar et al. (2014), Phonthanukitithaworn,et al. (2015), Dakduk et al. (2017) an d Wei et al. (2017) who found that the Perceived ease of use had a positive and significant effect on perceptions of usefulness .

\section{Implications Teor e tis}

\section{IMPLICATIONS OF RESEARCH RESULTS}

Based on the findings in this Litian pene, then the implication Teor e tis could be said that this research model, enrich the concept of consumer behavior in marketing, especially in the intention of using electronic money. The results of this study indicate that perceptions of usefulness, perceived ease and attitude have a positive and significant effect on the intention to use electronic money. The results also reinforce da n support the results of previous studies related to the intention of using electronic money. It is expected that the results of this study can be used as reference material in knowing the development of marketing strategies for electronic money products and the development of consumer behavior towards intentions or interests and consumer responses in using electronic money and / or other new products based on technology.

\section{Practical Implications}

Based on the results of the study obtained practical implications about the factors that influence the intention to use electronic money. Intention of use in this study is a consumer behavior where consumers have a desire to use an electronic money product. The factors that influence the intention to use in this study are perceptions of usefulness, perceived ease of use, and attitude. The results of this study also enable electronic money issuing companies, especially those domiciled in Denpasar, to be more aware of aspects that can improve and improve in promoting or implementing appropriate marketing strategies to increase the interest of the community's intention to use electronic money as a medium for future micropayment transactions .

\section{Conclusion}

\section{CONCLUSIONS AND RECOMMENDATIONS}

Based on the results of the discussions that have been carried out, the following conclusions are obtained:

1) Perceived usefulness and significant positive effect on the attitudes of the use of electronic money. This result means that the more a person feels that electronic money is beneficial, it will encourage someone to be positive about the use of electronic money.

2) Perceived usefulness positive and significant effect on the intention of use of electronic money. This means that the more someone feels electronic money is useful, the person will have more intention to use electronic money. 
3) The use of electronic money has a positive and significant effect on the intention to use electronic money. This means that the more a person has a positive attitude towards the use of electronic money, it will increase one's intention to use electronic money.

4) Perceived ease of use positive and significant impact on the attitudes of the use of electronic money. This means the more one feels feel the ease with electronic money then someone will increasingly have a positive attitude towards ua $\mathrm{n} g$ electronics.

5) Perceived ease of use positive and significant effect on the Perceived the usefulness of electronic money. This means that the more a person feels that the ease gained by using electronic money will improve one's perception related to the usefulness of electronic money.

\section{SUGGESTION}

After studying, analyzing, discussing and drawing conclusions, the writer gives some suggestions as a consideration in the future. The suggestions that can be submitted are as follows.

\section{For Practitioners}

Electronic money publishers who use electronic money will be more good if you can increase marketing related to the usefulness and usefulness of electronic money so that it can create a positive attitude for its users. Based on the characteristics of respondents, the dominant respondent's age is 24 years to 28 years. So that business people who issue electronic money to be more likely to target people aged 24 to 28 years because at that age the community tends to be interested in the renewal of payment technology, so this will further facilitate the spread of electronic money.

\section{For Academics}

Suggestions for future research are to be considered to conduct research in different places and also expand the research area and target respondents who are more specialized for example in adolescents or adults. Future studies are also expected to analyze the relationship mediation of variables - variables that exist in the TAM theory to measure and broader look factors that may affect attitudes and intentions in the use of a product. In the future, it is also expected that researchers can conduct research not only to measure intentions, but also to the variables of consumer behavior towards the intentions they obtain.

\section{RESEARCH LIMITATIONS}

1) This research scope only on the consumer electronic money products in Denpasar, so that research results can not be generalized to the consumer electronic money products in other regions.

2) This research only examines the extent to the intention of prospective consumers towards the use of electronic money, at where in TAM is it possible to conduct research to measure the attitudes of prospective consumers that arise as a result of the intention to use electronic money.

3) This research is only carried out in certain time points (cross section), while the environment changes every time (dynamic), so this research is important to be done again in the future.

\section{Reference}

Ajzen, I. 1991. 'The theory of planned behavior', Orgnizational Behavior dan Human Decision Processes. Academia Press .Inc. Vol. 50, pp. 179-211.

Akinci, S., Aksoy, Ş. dan Atilgan, E. 2004. 'Adoption of Internet banking among sophisticated consumer segments in an advanced developing country', International Journal of Bank Marketing. Vol. 22. No. 3, pp. 212-232. 
Alagoz dan Hekimoglu. 2012. 'A Study on Tam: Analysis of Customer Attitudes in Online Food Ordering System', Procedia - Social dan Behavioral Sciences. Vol. 6. No. 2, pp. 1138-1143.

Bhattacherjee, A. 2000. "Acceptance of e-commerce services: the case of electronic brokerages", IEEE Transactions on System, Man, dan Cybernetics-Part A: System Humans, Vol. 20. No. 4. pp. 411-20.

Chin, W.W.1998. The Partial least squares approach for structural equation modeling. in G.A. Marcoulides (Ed.), Modern methods for business research (pp.295-236). London: Lawrence Erbaum Associates.

Dakduk, S. Enrique ter Horst, Zuleyma Santalla, German Molina and José Malavé. 2017. 'Customer behavior in electronic commerce: A bayesian approach', Journal of Theoretical dan Applied Electronic Commerce Research, Vol. 12. No. 2, pp. 1-20.

Davis. 1989.S 'Perceived Usefulness , Perceived Ease Of Use , dan User Acceptance', MIS Quarterly, Vol. 13. No. 3, pp. 319-339.

Giovanis, A. N., Binioris, S. dan Polychronopoulos, G. 2012 'An extension of TAM model with IDT dan security/privacy risk in the adoption of internet banking services in Greece', EuroMed Journal of Business. Vol. 7. No. 1, pp. 24-53.

Hawkins. 2001. Consumer Behavior : Building Marketing Strategy, New York : McGraw-Hill Inc.

Hawkins, D.I, dan Mothersbaugh, D.I. 2010. Consumer Behaviour: Building Marketing Strategy.11 ${ }^{\text {th }}$ edition. New York:McGraw-Hill, Irwin.

Howard dan Sheth. 1979. The Theory of Nuyer Behaviour, New York, John Wiley.

Hsiao, C.-H. dan Tang, K.-Y. 2014. 'Explaining undergraduates' behavior intention of e-textbook adoption', Library Hi Tech, Vol. 32 No. 1, pp. 139-163.

Kotler, P dan Kevin , L, K.2006. Marketing Management 12e. Pearson International Edition. New Jersey.

Kotler, Philip, dan K.L. Keller. 2009. Manajemen Pemasaran. Diterjemahkan oleh Bob Sabran. Jakarta: Erlangga.

Latan, hengky, 2012. Structural Equation Modeling, Konsep dan Aplikasi Menggunakan Program Lisrel 8.80, Penerbit Alfabeta, Bandung.

Li, J,. Dick, m., Alvin, L. and Fang, L., 2008. “The Relationship Between Attitude dan Behavior; An Empirical Study in China". UWA Business School, The University of Western Australia, Crawley, Australia.

Ma, Yoon Jin, Hae Jin Gam and Jennifer Banning. 2017. 'Perceived ease of use dan usefulness of sustainability labels on apparel products: application of the technology acceptance model', Fashion dan Textiles. Springer Berlin Heidelberg, Vol. 4. No. 3. pp. 1-20.

Mafe. 2009. A Comparative study of mobile messaging service acceptance to participate in television programmes, Journal of Service Management, Vol. 2 No. 1. pp. 69-102.

Nugroho, Agung. 2005. Strategi Jitu Memilih Metode Statistic Penelitian dengan SPSS. Jogyakarta.

Peter, P.J., Olson, J. C. 2008. “Consumer Behavior in Marketing Strategy”. Eight Edition. McGraw-Hill International Edition.

Peslak, A., Ceccucci, W. dan Sendall, P. 2010, An Empirical Study of Instant Messaging (IM) Behavior Using Theory Of Reasoned Action.

Phonthanukitithaworn Chanchai, Carmine Sellitto and Michelle Fong, 2015. 'User Intentions to Adopt Mobile Payment Services: A Study of Early Adopters in Thailand CHANCHAI', Journal of Internet Banking dan Commerce, Vol. 20 No.1, pp. 1-11.

Rigopoulos dan Askounis. 2007. A TAM Framework to Evaluate Users' Perception towards Online Electronic Payments, Journal of Internet Banking dan Commerce, Vol. 12. No. 3. pp. 1-20.

Safeena R. Hema Date, Nisar Hundewale, and Abdullah Kammani. 2013. 'Combination of TAM dan TPB in Internet Banking Adoption', International Journal of Computer Theory dan Engineering, Vol. 5. No. 1. pp. 146-150.

Schiffman, L.G dan Kanuk, L.K, 2010. “Consumer Behavior”, $10^{\text {th }}$ edition. New Jersey, Pearson Prentice Hall.

Sugiyono, 2015. Metode Penelitian Kuantitatif Kualitatif dan RdanD. Bandung. Afabeta.

Taylor, S. dan Todd, P.A. 1995. Decomposition dan Crossover Effects in the Theory of Planned Behavior: A Study of Consumer Adoption Intentions. International Journal of Research in Marketing, Vol. 1 No. 2. pp. 137-55. 
Taylor, S dan Tood, P.A. 1955c, Understanding Information Technology Usage: A Test of Competing Models, Information System Research, Vol. 6. No. 2. pp. 144-76.

Wei, Qijun Xie, Song Xiaobao Peng, and Muhammad Shabbir. 2017 'Predictors for e-government adoption: integrating TAM, TPB, trust dan perceived risk', The Electronic Library, Vol. 35. No. 1. pp. 2-20.

Yadav, R., Chauhan, V. dan Pathak, G. S. 2015 'Intention to adopt internet banking in an emerging economy: a perspective of Indian youth', International Journal of Bank Marketing, 334, pp. 530-544. doi: 10.1108/EL-012014-0022.

\section{Online Source :}

htttp://www.bi.go.id

http://www.bisnis.com 